\title{
Chapter 8 \\ Rural-Urban Migration, Urbanization, and Wage Differentials in Urban India
}

\author{
Jajati Keshari Parida
}

\section{Introduction}

The Indian economy has been through a rapid economic growth phase since early 2000s, which was accompanied by structural changes in both output and employment. The share of the Gross Domestic Product (GDP) in the agriculture, industry, and service sectors has changed from $24 \%$ to $14 \%, 27 \%$ to $28 \%$, and $49 \%$ to $58 \%$, respectively, from 2000-2001 to 2011-2012. The share of employment in agriculture decreased from $61 \%$ to $49 \%$; in industry, it increased from $15.5 \%$ to $24.3 \%$; and in services, it increased from $22.5 \%$ to $26.7 \%$ during the same period (see Parida 2015). For the first time in the history of India, an absolute decline (23.7 million) in agricultural employment was noticed during 2004-2005 and 2009-2010, of which 22.5 million were unpaid family workers (see Appendix Table 8.8). These are the workers whose marginal productivity is very low. The substantial increase (about 25 million) in nonfarm employment (16 million in industry and 9 million in services) during this period, on the other hand, clearly indicates a Lewisian (Lewis 1954) transition in India. On the demand side, agricultural distress ${ }^{1}$ (see Abraham 2008), mechanization in agriculture (see Himanshu 2011 and Mehrotra et al. 2014), and rising agricultural/rural wages (Gulati et al. 2013 and Mehrotra et al. 2014) were the major factors leading to the decline in the agriculture workforce. On the supply side, the withdrawal of female workers from agriculture (Mehrotra et al. 2014) and increasing participation in education in recent years (see Kannan and Raveendran,

I am highly thankful to S. Mehrotra, S. Madheswaran, E. Wilson, G. Wan, K. Jayanthakumaran, G. Sugiyarto, and R. Verma, for their valuable comments and suggestions. The views expressed in the study do not necessarily reflect those of the Government of India.

${ }^{1}$ This distress is partly reflected by the growing farmer suicides in India (see Gill and Singh 2006; Mitra and Shroff 2007; and Jeromi 2007 for details).

J. K. Parida $(\bowtie)$

Centre for Economic Studies, Central University of Punjab, Bathinda, Punjab, India 
2012; Rangarajan et al. 2011; Thomas 2012; and Mehrotra and Parida 2017) would sustain this rural to urban migration process for the next few years in India.

In the Lewisian transition process, it is expected that labor productivity will increase as the surplus laborers (mainly underemployed workers) in agriculture move to the modern sector. Recent studies on employment trends in India (see Mehrotra et al. 2014; and Parida 2015) state that workers leaving agriculture are mainly employed in construction; labor-intensive manufacturing units like textile, wearing apparel, leather and wood products, and manufacture of furniture; services like trade, hotels, and restaurant, transport and communications, and financial services; etc. Earlier studies of migrant workers like Joshi and Joshi (1976), Dupont (1992), Kundu and Gupta (1996), Srivastava (1998), Singh (2002), Bhattacharya (2002), Mitra (2003), Vijay (2005), and Deshingkar and Akter (2009) have found that migrant unskilled or semiskilled workers in small towns and suburban areas are normally employed in either construction (including brickmaking, stone quarries, and mines), textiles (mostly in small-scale and marginal enterprises), hospitality services, etc. Given the significance of rural-urban migration in the process of economic growth in India, it is important to know: (1) What is the volume and pattern of rural to urban migration and what factors are driving these in India? (2) What is the share of migrants and their employment patterns in urban India? (3) What role does rural to urban migration play in the processes of urbanization, informalization, and slum development in India? (4) What are the factors that determine the workforce participation decision of migrants and non-migrants in urban India? (5) Is there any productivity/wage difference between migrants and non-migrant workers, and if so, what accounts for it in urban India? This paper tries to answer these questions using the national-level migration survey data collected by the National Sample Survey Organization (NSSO).

This chapter is organized as follows: Section two explains the data and econometric methodology used in the empirical estimation of migration, workforce participation decisions, and factors determining the earnings/wages of migrants and non-migrants and wage gaps between them. Section three explores the recent trends of rural-urban migration, the trends and composition of urban population growth, the patterns and structure of migrants' employment in urban India, and the factors determining migration decision and workforce participation in India. Section four estimates the wage/earning differential between migrant and non-migrant (native) workers and decomposes this wage differential to assess its composition in urban India. Finally, section five focuses on the conclusion and policy recommendations.

\section{Data and Econometric Methods}

This paper is based on secondary data. The unit-level data collected by the National Sample Survey Organization (NSSO) of India in its 55th (1999-2000) and 64th (2007-2008) rounds of migration-specific surveys are used for the analysis. These surveys provide a comprehensive national coverage: a sample size of 819,013 
persons (509,779 rural and 309,234 urban) during 1999-2000 and 572,254 persons (374,294 rural and 197,960 urban) during 2007-2008 at the national level. Both these surveys provide both family- and individual-level information on various socioeconomic indicators. The absolute volume of migration is estimated and adjusted to the Census population to get the exact approximation. The data on poverty head count ratio is taken from the estimates of the Planning Commission (2004-2005) whereas the average expenses (during 2003-2004 to 2006-2007) on subsidizing agricultural equipment (a proxy for mechanization in agriculture) and state-wise minimum wages of unskilled agriculture workers are taken from the Ministry of Agriculture. Rural and urban population data are taken from the Census of India.

Migration and workforce participation decision functions are estimated using the bivariate probit model. This is in line with the Mincerian (Mincer 1974) wage model. The Mincerian wage equations of both migrants and non-migrants are estimated after controlling for the selection bias (see Heckman 1979). And finally, the wage/earning differential between them (migrants and natives of the town/city) is decomposed using the Oaxaca-Blinder method (see Oaxaca 1973; and Blinder 1973). The formal derivation of the bivariate probit regression, the Mincerian wage equation, and the Oaxaca-Blinder decomposition methods are given below:

A bivariate probit model involves two equations (each equation is a binary choice model). The model is as follows:

$$
\begin{aligned}
& y_{i 1}=X_{\mathrm{i} 1} \beta_{1}+\varepsilon_{\mathrm{i} 1} \quad y_{\mathrm{i} 1}=1 \text { if } y_{\mathrm{i} 1}^{*}>0 ; \text { and }=0, \text { otherwise } \\
& y_{\mathrm{i} 2}=X_{\mathrm{i} 2} \beta_{21}+\varepsilon_{\mathrm{i} 2} \quad y_{\mathrm{i} 2}=1 \text { if } y_{\mathrm{i} 2}^{*}>0 ; \text { and }=0, \text { otherwise } \\
& E\left(\varepsilon_{\mathrm{i} 1}\right) \text { and } E\left(\varepsilon_{\mathrm{i} 2}\right) \text { are equal to zero; } \\
& \operatorname{var}\left(\varepsilon_{\mathrm{i} 1}\right) \text { and } \operatorname{var}\left(\varepsilon_{\mathrm{i} 2}\right) \text { are equal to one; and } \\
& \operatorname{cov}\left(\varepsilon_{\mathrm{i} 1}, \varepsilon_{\mathrm{i} 2}\right)=\rho ; \mathrm{i}=1,2,3 \ldots, \mathrm{n}
\end{aligned}
$$

Using Eq. 8.1, a standard probit model can be set as:

$$
\begin{aligned}
& \operatorname{Pr}\left[y_{\mathrm{i} 1}=1\right]=\operatorname{Pr} \cdot\left[y_{\mathrm{i} 1}^{*}>0\right]=\operatorname{Pr}\left[X_{\mathrm{i} 1} \beta_{1}+\varepsilon_{\mathrm{i} 1}>0\right] \\
& =\operatorname{Pr}\left[\varepsilon_{\mathrm{i} 1}>-X_{\mathrm{i} 1} \beta_{1}\right]=\operatorname{Pr}\left[\varepsilon_{\mathrm{i} 1}<X_{\mathrm{i} 1} \beta_{1}\right]=\varphi\left(X_{\mathrm{i} 1} \beta_{1}\right)
\end{aligned}
$$

where $\phi($.$) implies the cumulative distribution function of the standard normal. We$ have used symmetry of the normal distribution to get the penultimate equality above. To set up the bivariate probit model, based on both Eqs. (8.1) and (8.2), we need to consider the following four possible cases:

$$
P_{11}=\operatorname{Pr}\left[y_{\mathrm{i} 1}=1, \quad y_{\mathrm{i} 2}=1\right]=\int_{-\infty}^{X_{\mathrm{i} 1} \beta_{1} X_{\mathrm{i} 2} \beta_{21}} \int_{-\infty}^{2} \varphi_{2}\left(z_{1},, z_{2}, \rho\right) \mathrm{d} z_{1} \mathrm{~d} z_{2}
$$




$$
\begin{gathered}
P_{10}=\operatorname{Pr}\left[y_{i 1}=1, \quad y_{i 2}=0\right]=\int_{-\infty}^{X_{i 1} \beta_{1}} \int_{X_{i 2} \beta_{21}}^{\infty} \varphi_{2}\left(z_{1}, z_{2},, \rho\right) d z_{1} d z_{2} \\
P_{01}=\operatorname{Pr}\left[y_{i 1}=0, \quad y_{i 2}=1\right]=\int_{X_{i 1} \beta_{1}}^{\infty} \int_{-\infty}^{X_{i 2} \beta_{21}} \varphi_{2}\left(z_{1}, z_{2}, \rho\right) d z_{1} d z_{2} \\
P_{00}=\operatorname{Pr}[0]=\int_{X_{\mathrm{i} 1} \beta_{1}}^{\infty} \int_{X_{\mathrm{i} 2} \beta_{21}}^{\infty} \varphi_{2}\left(z_{1}, z_{2}, \rho\right) d z_{1} d z_{2}
\end{gathered}
$$

where the bivariate normal density function is

$$
\varphi\left(z_{1}, z_{2},, \rho\right)=\exp \left(\frac{-0.5\left(Z_{1}^{2}+Z_{2}^{2}-2 \rho Z_{1} Z_{2}\right)}{\left(1-\rho^{2}\right) / 2 \pi\left(1-\rho^{2}\right)^{1 / 2}}\right)
$$

The estimates based on this formulation are given in Table 8.3.

The Mincerian earning equation is given as

$$
\ln \left(W_{\mathrm{i}}\right)=X_{\mathrm{i}} \beta+\delta M_{\mathrm{i}}+\varepsilon_{\mathrm{i}}
$$

where $\ln \left(W_{\mathrm{i}}\right)$ is the logarithm (natural) of monthly wages, $X_{\mathrm{i}}$ is a vector of regressors, $\beta, \delta$ are parameters, and $\varepsilon$ is stochastic disturbance term. This equation is problematic because it does not take the self-selection bias in migration and workforce decision into account. Hence, instead of $\mathrm{M}_{\mathrm{i}}$ (a single dummy), two distinct wage equations are estimated (one for migrants $\left(W_{\mathrm{im}}\right)$ and the other for non-migrants $\left.\left(W_{\text {in }}\right)\right)$. To control for the selection bias, two selectivity controls variables (inverse Mills ratios) are included in these equations:

$$
\begin{gathered}
\ln \left(W_{i m}\right)=X_{i m} \beta+\delta_{1} \lambda_{m}+\delta_{2} \lambda_{e}+\varepsilon_{i m} \\
\ln \left(W_{i n}\right)=X_{i n} \beta+\delta_{1} \lambda_{n}+\delta_{2} \lambda_{e}+\varepsilon_{i n}
\end{gathered}
$$

where $\lambda_{\mathrm{m}}$ (migration) and $\lambda_{\mathrm{e}}$ (employment) are selection correction variables and $\varepsilon_{\mathrm{im}}$ and $\varepsilon_{\text {in }}$ are stochastic error terms which are normally distributed having zero mean and constant variances $\left(\sigma_{\text {im }}^{2}\right.$ and $\sigma_{\text {in). }}^{2}$ The estimates based on (8.4) and (8.5) are given in Table 8.5. Rewriting Eqs. 8.4 and 8.5 as

$$
\begin{gathered}
\ln \bar{W}_{\mathrm{im}}=\sum \hat{\beta}_{\mathrm{m}} \bar{X}_{\mathrm{im}}+\varepsilon_{\mathrm{im}} \quad \text { (Migrants'wage equation) } \\
\ln \bar{W}_{\mathrm{in}}=\sum \hat{\beta}_{\mathrm{n}} \bar{X}_{\mathrm{ni}}+\varepsilon_{\mathrm{in}} \quad(\text { Non-migrants' wage equation) }
\end{gathered}
$$

In this framework, gross wage differential is 


$$
\ln \bar{W}_{\text {im }}-\ln \bar{W}_{\text {in }}=\sum \hat{\beta}_{\mathrm{m}} \bar{X}_{\text {im }}-\sum \hat{\beta}_{\mathrm{n}} \bar{X}_{\text {in }}
$$

In Oaxaca decomposition method, Eq. 8.8 is expanded. For a specific endowment, if migrants were paid as per non-migrants wage structure (no discrimination case), then migrant's earning function would be

$$
\ln \bar{W}_{\mathrm{im}}=\sum \hat{\beta}_{\mathrm{n}} \bar{X}_{\mathrm{im}}
$$

Subtracting Eq. (8.9) from Eq. (8.8), we get

$$
\begin{aligned}
& \ln \bar{W}_{\mathrm{im}}-\ln \bar{W}_{\mathrm{in}}-\ln \bar{W}_{\mathrm{im}}=\sum \hat{\beta}_{\mathrm{m}} \bar{X}_{\mathrm{im}}-\sum \hat{\beta_{\mathrm{n}}} \bar{X}_{\mathrm{in}}-\sum \hat{\beta}_{\mathrm{n}} \bar{X}_{\mathrm{im}} \\
& \Rightarrow \ln \bar{W}_{\mathrm{im}}-\ln \bar{W}_{\mathrm{in}}-\sum \hat{\beta}_{\mathrm{n}} \bar{X}_{\mathrm{im}}=\sum \hat{\beta}_{\mathrm{m}} \bar{X}_{\mathrm{im}}-\sum \hat{\beta}_{\mathrm{n}} \bar{X}_{\mathrm{in}}-\sum \hat{\beta}_{\mathrm{n}} \bar{X}_{\mathrm{im}} \\
& \Rightarrow \ln \bar{W}_{\mathrm{im}}-\ln \bar{W}_{\mathrm{in}}=\sum \hat{\beta}_{\mathrm{m}}\left(\bar{X}_{\mathrm{im}}-\bar{X}_{\mathrm{in}}\right)+\sum \bar{X}_{\mathrm{im}}\left(\hat{\beta}_{\mathrm{m}}-\hat{\beta}_{\mathrm{n}}\right)
\end{aligned}
$$

Alternatively, the decomposition can also be done as

$$
\ln \bar{W}_{\mathrm{im}}-\ln \bar{W}_{\mathrm{in}}=\sum \hat{\beta}_{\mathrm{n}}\left(\bar{X}_{\mathrm{im}}-\bar{X}_{\mathrm{in}}\right)+\sum \bar{X}_{\mathrm{in}}\left(\hat{\beta}_{\mathrm{m}}-\hat{\beta}_{\mathrm{n}}\right)
$$

In Eqs. (8.10) and (8.11), the terms on the right-hand side are termed as endowment differences and are unexplained (or discrimination) components. The determination of the components of the twofold decomposition is more complicated because an estimate for the unknown nondiscriminatory coefficients vector $\beta^{*}$ is needed. Several suggestions have been made in the literature. For example, there may be reasons to assume that discrimination is directed toward one of the groups only, so that $\beta^{*}=\beta_{\mathrm{m}}$ or $\beta^{*}=\beta_{\mathrm{n}}$ (see Oaxaca 1973, who speaks of an "index number problem"). If wage discrimination is only directed against one group, there will be no problem, but, there is no definite reason to assume this (Madheswaran and Attewell 2007). However, Cotton (1988) argued that the undervaluation of one group comes along with an overvaluation of the other. Reimers (1983) proposed to use the average coefficients of both these groups as an estimate of the nondiscriminatory parameters, i.e., $\hat{\beta}^{*}=0.5 \hat{\beta}_{\mathrm{m}}+0.5 \hat{\beta}_{\mathrm{n}}$. The weight suggested by Cotton (1988) is based on the coefficient of group sizes of migrants $\left(N_{\mathrm{m}}\right)$ and non-migrants $\left(N_{\mathrm{n}}\right)$, that is,

$$
\hat{\beta}^{*}=\left(\frac{N_{\mathrm{m}}}{N_{\mathrm{m}}+N_{\mathrm{n}}}\right) \hat{\beta}_{\mathrm{m}}+\left(\frac{N_{\mathrm{n}}}{N_{\mathrm{m}}+N_{\mathrm{n}}}\right) \hat{\beta}_{\mathrm{n}}
$$

On the other hand, Neumark (1988) suggested to use coefficients of the pooled regression $\left(\beta^{*}\right)$. The empirical estimates based on the above formulations are given in Tables 8.6 and 8.7. 


\section{Rural-Urban Migration, Urbanization, and Employment in Urban India}

\subsection{Rural-Urban Migration Trends in India}

During the period of structural transformation in India, a large number of people out-migrated from rural areas. The number of out-migrants increased by 42 million (about 24\% increase) during 1999-2000 and 2007-2008. The total number of outmigrants (within the Indian geographical territory) was about 175.3 million during 1999-2000. This increased to about 216.8 million during 2007-2008 (see Table 8.1). Both the number and percentage of out-migrants are high in relatively poor and backward states, most of which are agrarian. These states ${ }^{2}$ include Orissa (Odisha), Bihar, Chhattisgarh, Jharkhand, Madhya Pradesh, Uttar Pradesh, and Andhra Pradesh. In terms of the number of rural out-migration, Uttar Pradesh stands at the top position during 1999-2000 (35.6 million) and 2007-2008 (about 37 million) with an absolute increase in the same of 1.3 million. Maharashtra registered the second highest number of rural out-migrants followed by Andhra Pradesh during 2007-2008. In terms of the increase in out-migration, Chhattisgarh is followed by Andhra Pradesh and Bihar. It is important to note that the states with relatively high poverty headcount ratio (HCR) are showing a large number of rural out-migrations in India.

The continuous growth of rural population and lack of nonfarm employment opportunities in rural areas could have caused a huge increase in agricultural employment during 2004-2005 (see Appendix Table 8.8) with most of it being unpaid family members. However, during post 2004-2005 periods, growing mechanization $^{3}$ (as evident from the increase in average government expenses on subsidizing agricultural equipment to farmers across the states in India) in agriculture on one hand and increasing rural unemployment ${ }^{4}$ rate (current daily status (CDS)) in some states, on the other, led huge segments of the rural population to migrate. The increase in rural literacy rates (particularly due to Sarva Shiksha Abhiyan and Right to Education) during these periods would also have enabled a large segment of the rural educated youth to migrate. The rural out-migrants working in urban industry and service sectors would increase labor productivity (Lewis, 1954), and that would boost economic growth. Hence, it is important to know where these migrants go.

\footnotetext{
${ }^{2}$ The correlation efficient between poverty headcount ratio (HCR) and rural out-migration is positive $(0.43)$

${ }^{3}$ The correlation between mechanization in agriculture and rural out-migration is positive $(0.52)$.

${ }^{4} \mathrm{As}$ the correlation between rural unemployment and out-migration is positive $(0.06)$.
} 


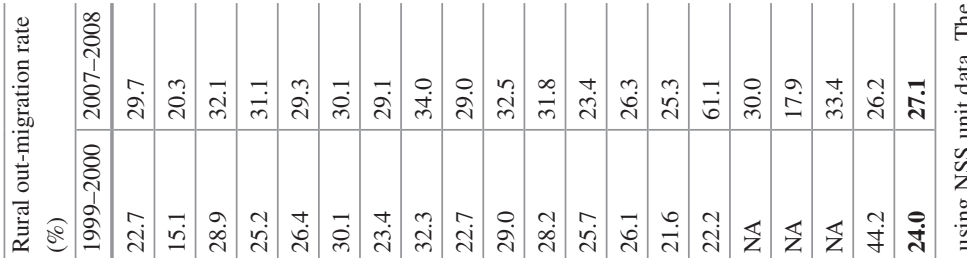

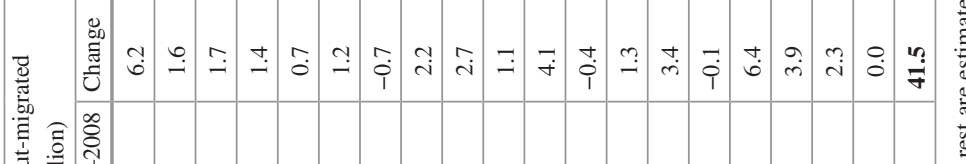

$\stackrel{\circ}{\circ}$

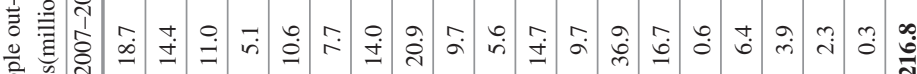

1 娄

ธิ8

承

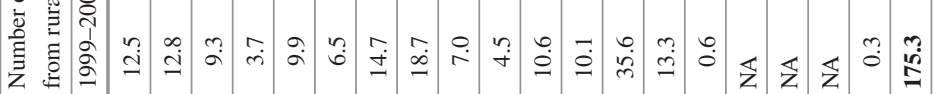

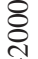

ळे

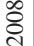

差

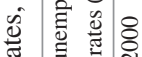

露 $\overrightarrow{0}$

.⿹\zh26灬

$\Xi$

$\frac{\sqrt{0}}{\frac{8}{4}}$

के

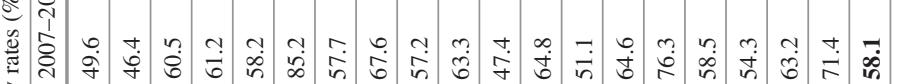

.

悹

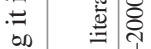

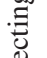

골

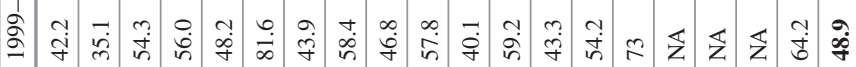

$\stackrel{0}{0}$

政

总

$\stackrel{0}{ \pm}$

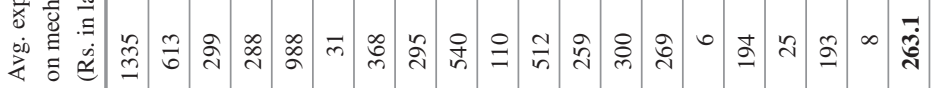

穿 两

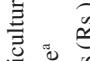

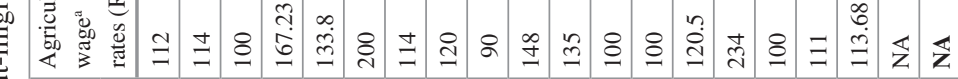

总

D.

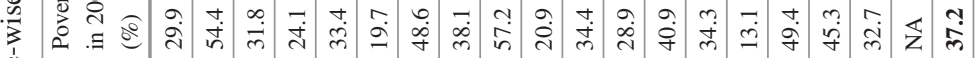

苟

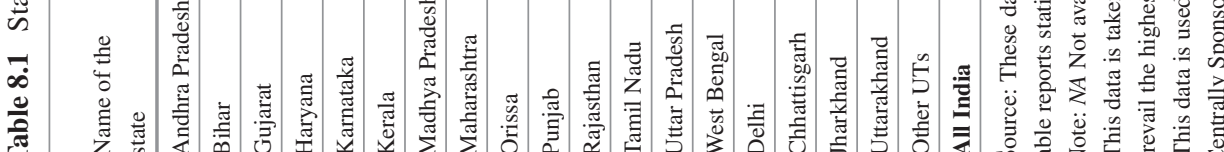

产

竞.

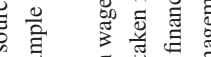

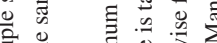

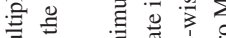

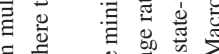

ह $\frac{5}{3}$.

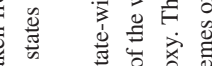

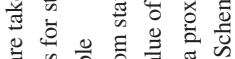

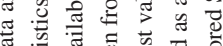

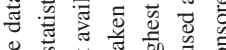

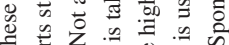




\subsection{Rural to Urban Migration and Urbanization in India}

A huge share of the rural out-migrants is residing in urban areas, as the absolute number of in-migrants in urban India increased by about 23.2 million (from 93.6 million in 1999-2000 to 116.8 million in 2007-2008) or about 3 million per annum (see Table 8.2). The census data also reflect the same (Fig. 8.1). According to census population data, while the about 40 million growth in urban population is due to natural growth, about 22 million is due to rural to urban migration during 2001 and 2011. The share of natural growth in the urban population in India decreased from $59 \%$ to $44 \%$, while the share of migrant population increased from $21 \%$ to $24 \%$ (Fig. 8.1).

Migrants contributed massively to the increase in urban population (Fig. 8.1) in recent years, which is clearly reflected with the increasing share of migrants in the urban population across the states of India. The share of migrants increased from $33.3 \%$ in $1990-2000$ to $35.5 \%$ in $2007-2008$. In Maharashtra, Delhi, Haryana, Andhra Pradesh, Orissa, Chhattisgarh, and Uttarakhand, this share is more than $40 \%$ (Table 8.2), while in a few other states, this share is above the national average in 2007-2008. In India, out of the total migrants in urban areas, about $60 \%$ have come from rural areas. A similar observation is made across the states of India. This shows the "Lewisian transition" occurring during the post 2004-2005 periods in India.

The states receiving the highest numbers of urban in-migrants are Maharashtra (20.3 million), Uttar Pradesh (13.3 million), Andhra Pradesh (about 10.5 million), Gujarat (8.3 million), Tamil Nadu (8.3 million), West Bengal (about 8.2 million), Karnataka (about 6.4 million), Delhi (about 6.2 million), and Rajasthan (6.1 million). But the states that registered the highest increase in the absolute number of migrants include Delhi (about 6 million), Maharashtra (3.25 million), Gujarat (2.2 million), Rajasthan (1.66 million), Andhra Pradesh (1.5 million), West Bengal (1.23 million), and Karnataka (1.22 million). Most of the large metro and medium-sized cities of India belong to these states. This clearly indicates the fact that most rural migrants are attracted to both large and medium-sized cities. However, the natural growth of population in small and medium cities is probably higher than that of the big cities like Mumbai, Delhi, Kolkata, and Chennai. This is clearly reflected in Fig. 8.2.

\subsection{Rural to Urban Migration and Urban Employment in India}

The share of migrants in the urban workforce is greater than that of their share in the total urban population. During 1999-2000 and 2007-2008, 37\% of the total urban workers were migrants. The share of migrants in the workforce was highest (about $59 \%$ ) in Delhi and Maharashtra (about 50\%). It is important to note that two of the major metro cities, viz., New Delhi and Mumbai, are in these states. The share of migrants in the workforce is also more than the national average in most of the 


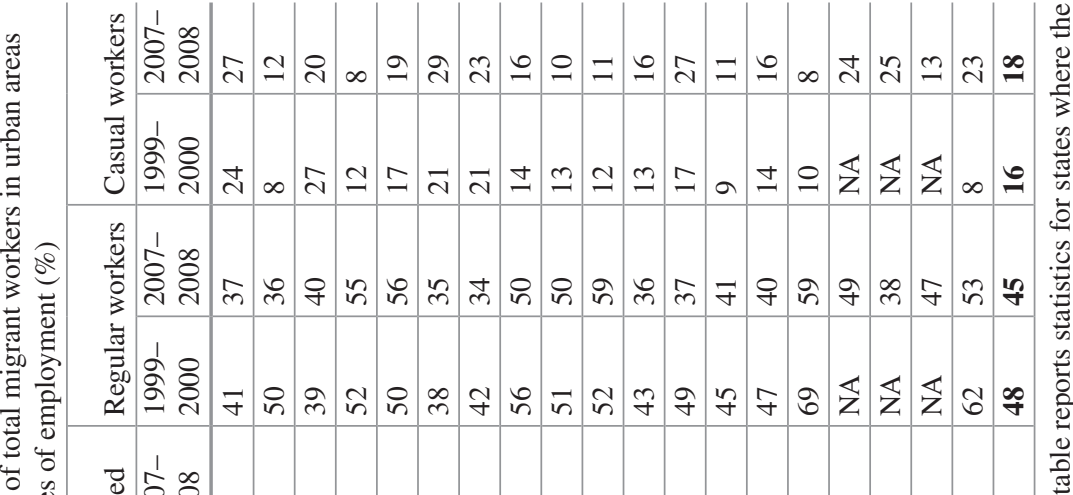

立. 氕

8

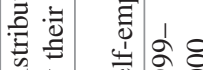

â

:

ลे ڤै

焉

-

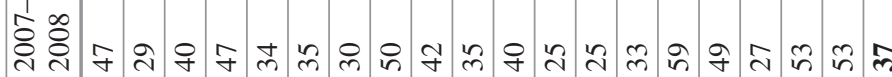

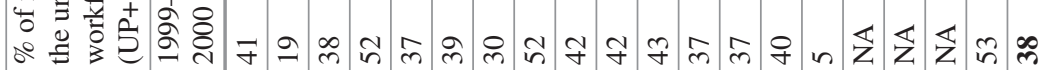

సี

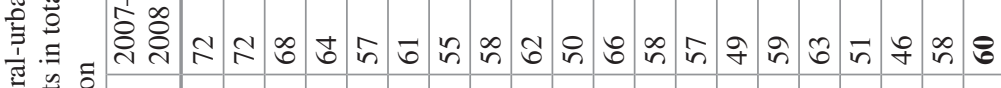

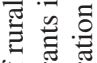

。‥

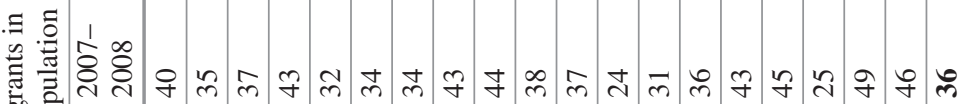
.0.0.

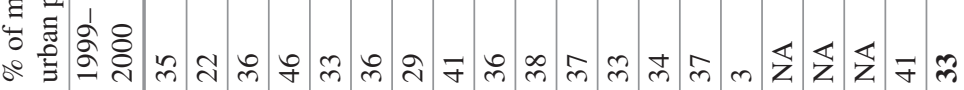

ह

द्वे

할

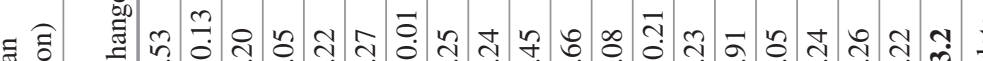
ฮี

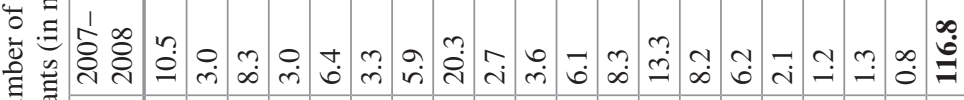

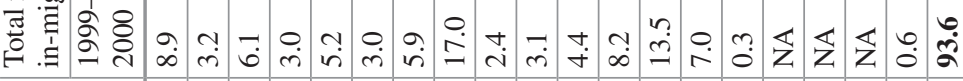

8

咅

雚

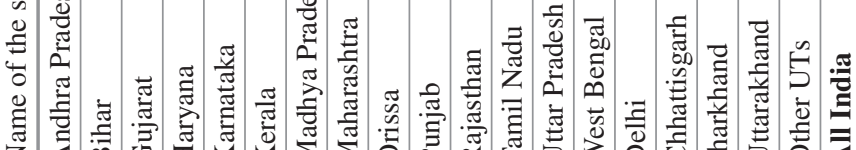

กิ

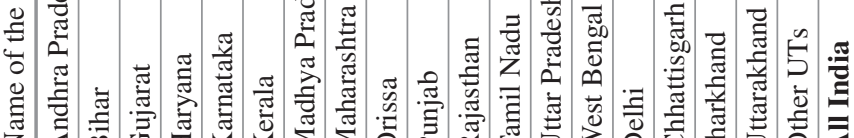

जี 

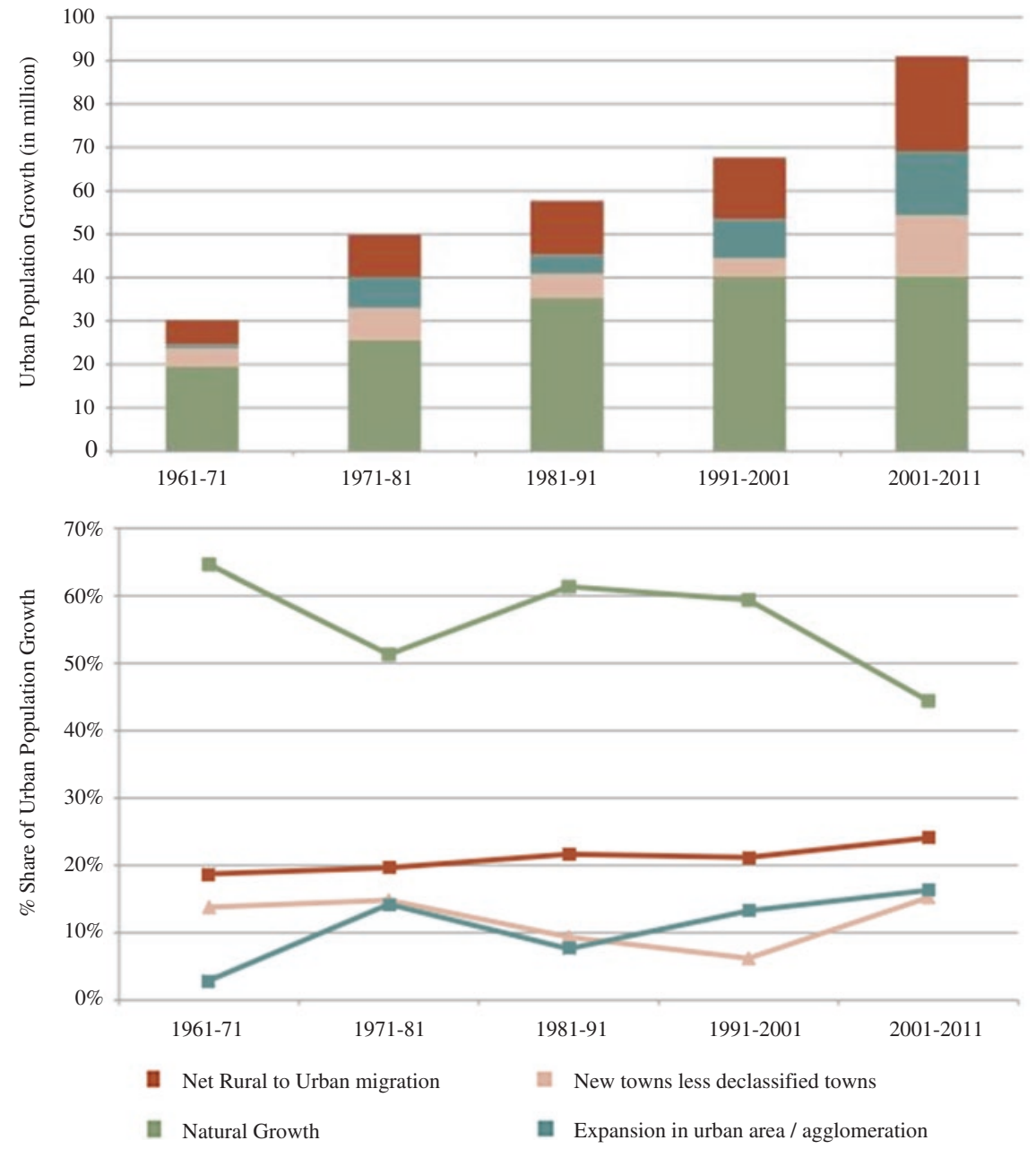

Fig. 8.1 Share of urban population growth in India, 1961-2011. Note: The colors in the top panel (bar graph) correspond to the color in the bottom panel (line graph). (Source: IIHS analysis based on Census of India, 2011 (Indian Institute of Human Settlement 2011, page 43))

states that registered relatively higher rural out-migration. Out of the total migrant workers, the percentage share of self-employed was about $36 \%$, regular-salaried workers was about $48 \%$, and casual workers was $16 \%$, respectively, in 1999-2000.

The percentage share of the self-employed increased to $37 \%$, regular-salaried workers declined to $45 \%$, and casual workers increased to $18 \%$, respectively, in 2007-2008. The share of regular-salaried workers declined across the states of India. During 1999-2000 and 2007-2008, the share of regular workers declined from 69\% to $59 \%$ in Delhi, from $56 \%$ to $50 \%$ in Maharashtra, from $49 \%$ to $37 \%$ in Tamil Nadu, from $47 \%$ to $40 \%$ in West Bengal, from $45 \%$ to $41 \%$ in Uttar Pradesh, from $41 \%$ to 


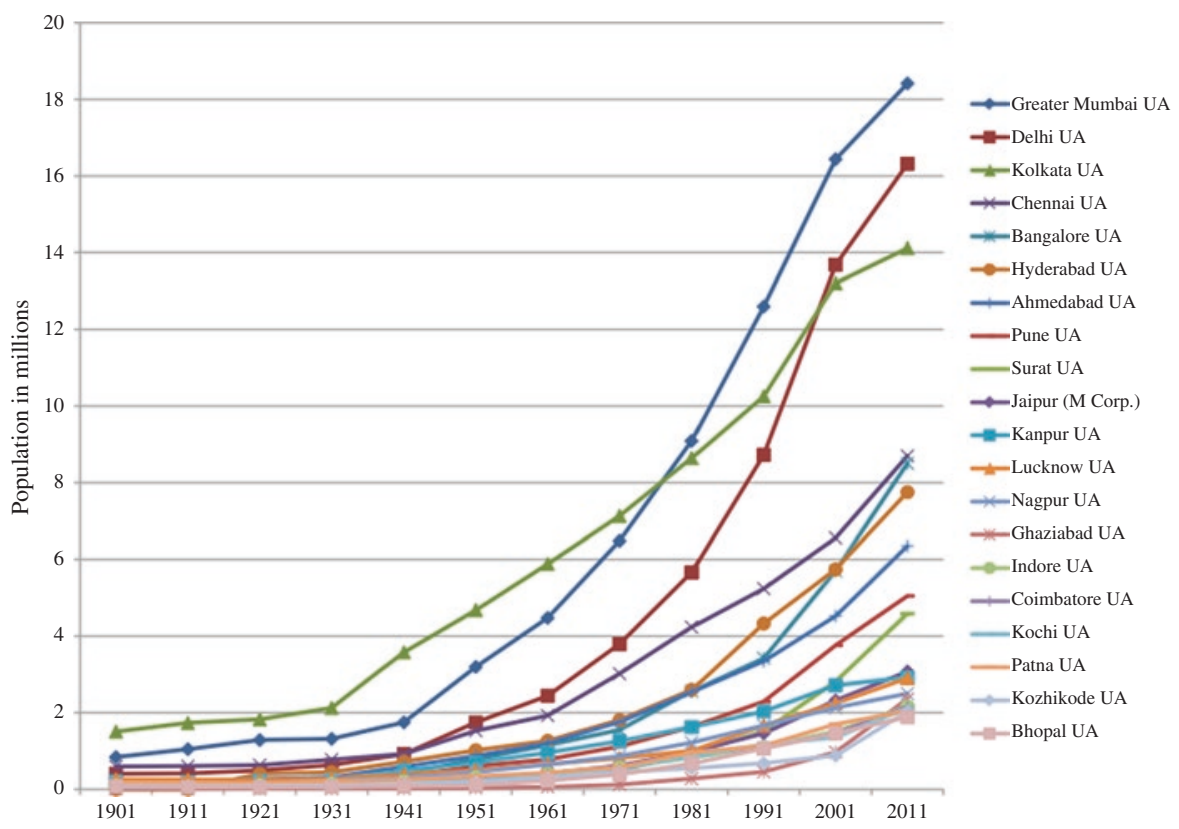

Fig. 8.2 Total population in the major cities of India. Note: UA stands for urban area. (Source: IIHS analysis based on Census of India, 2011 (Indian Institute of Human Settlement 2011, page 13))

37\% in Andhra Pradesh, and from 40\% to 39\% in Gujarat, respectively. An increasing share of self-employed and casual employment along with a corresponding declining share of regular workers indicate that there was a high inflow of low-skilled and unskilled workers into the urban areas, of which most are from rural areas. The unskilled and semiskilled workers from rural areas are most likely to work as either casual laborers or be self-employed by opening small shops or engaging themselves in petty trade, street vending, rickshaw pulling or auto rickshaw driving, etc.

The share of regular migrant workers, however, increased in a few states like Punjab, Haryana, and Karnataka. It might be due to the fact that the emerging techno-cities like Bangalore (Bengaluru) in Karnataka, Gurgaon in Haryana, and Chandigarh in Punjab attracted lots of modern service sector workers in recent years. Most of them are expected to be highly qualified and skilled in their respective domains. However, earlier studies on migrant labor like Connell et al. (1976) and Joshi and Joshi (1976) have found that relatively poorer households are mainly participating in the rural-urban migration process. These migrants move either permanently or semi-permanently, and most of them are engaged in the informal/unorganized sector. The findings of Srivastava and Bhattacharya (2002) and Deshingkar and Akter (2009) also show increased rural-urban employment in India. Given the intricacy of this phenomenon, it is important to find out the individual- and household-level factors that drive the rural to urban migration decision of individuals and their workforce participation in urban India. 
The estimated results of migration and labor force participation decisions are given in Table 8.3. A positive and significant $\rho$ suggests that both these decisions are influenced by the same set of random forces. A positive sign indicates that unobservables, those that determine labor force participation decision, are likely to positively influence migration decision too. Age, sex, marital status, education, landholdings, standard of living, castes, and religion influence both decisions.

A positive sign for the age coefficient and negative sign for age squared terms reflect the true labor market phenomenon. With increasing age, individuals' chance of migrating to urban areas increases and hence their participation in the urban workforce. However, after a certain age, they tend to withdraw from the workforce and are less likely to migrate. Sex dummy is negative in the migration equation and it is positive in the labor force participation equation. This is obvious as Indian females (reference category) migrate for marriage in increasing numbers to accompany their husbands or go to their in-law's place. Nevertheless, the coefficient of migration and sex interaction dummy reflects that the probability of labor force participation of male migrants is relatively higher than their female counterparts. The coefficient of marital status dummy indicates that other things being constant, individuals currently married, on average, migrate more and are likely to participate in the workforce as compared to their unmarried (reference category) counterparts. This precisely reflects the Indian society, in which the household responsibility of individuals normally increases after marriage. The coefficients of widowed and divorced/separated are showing positive signs, reflecting greater participation as compared to unmarried individuals.

The unexpected negative signs of general education dummies (illiterates are the reference category) indicate the fact that during these transition phases, more children are participating in general education and hence are less likely to participate in migration and the workforce. This result supports the findings of Rangarajan et al. (2011), Kannan and Raveendran (2012), Thomas (2012), and Mehrotra et al. (2014) which suggest that the recent increase in enrollments at various levels restricts the growth of the labor force size and hence the workforce. However, individuals with better skills (those having either a below graduate- or a graduate-level technical degree) are more likely to participate in both the decisions as compared to individuals with no technical education (reference category). This result is as expected in the period of a high growth regime.

The coefficients of landholding dummies (reference category landless) indicate that the probability of migration among the landless is higher as compared to others. This is again a clear indication of the "Lewisian transition" in India, as the coefficients of landholding dummies are negative and are increasing with the increase in the size of holdings. The coefficients of monthly per capita expenditure (MPCE) dummies, on the other hand, explain the aspiration aspect of rural to urban migration, as these coefficients are showing positive signs with a relatively higher value of the coefficients in higher MPCE categories. Despite a high probability to migrate, few other caste (mostly general castes) people have a high chance of entering the labor market as compared to scheduled caste (SC), scheduled tribes (ST), and other backward classes (OBC). While comparing across religion categories, it is found 


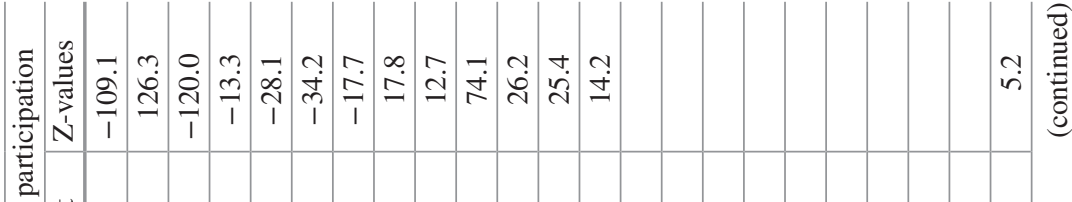

8 :

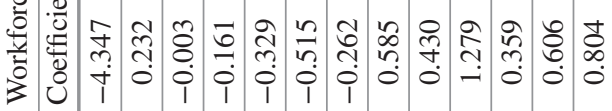

官

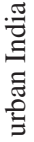

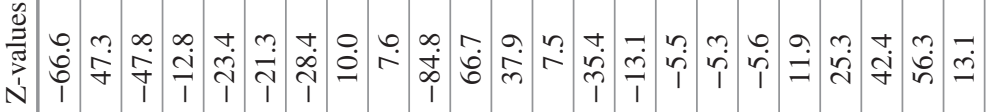

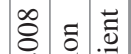

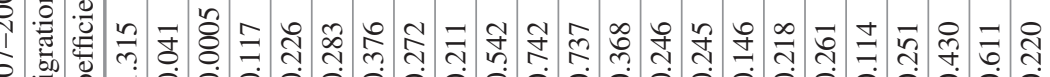

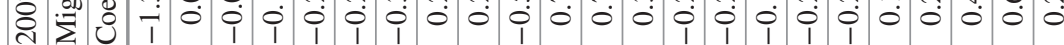

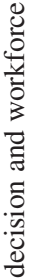

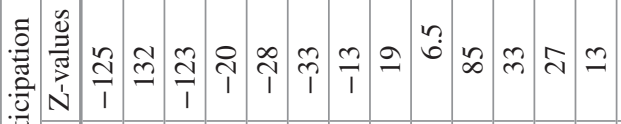

m?

范

\& $\overrightarrow{0}$

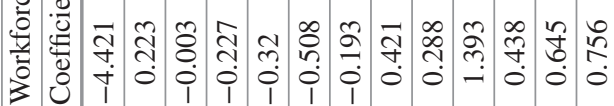

$\underset{\square}{\grave{0}}$

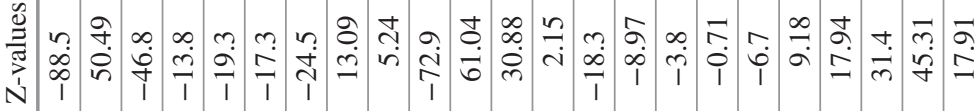

융. 흘

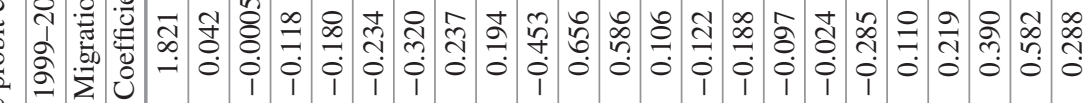

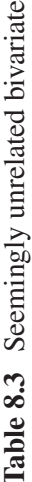

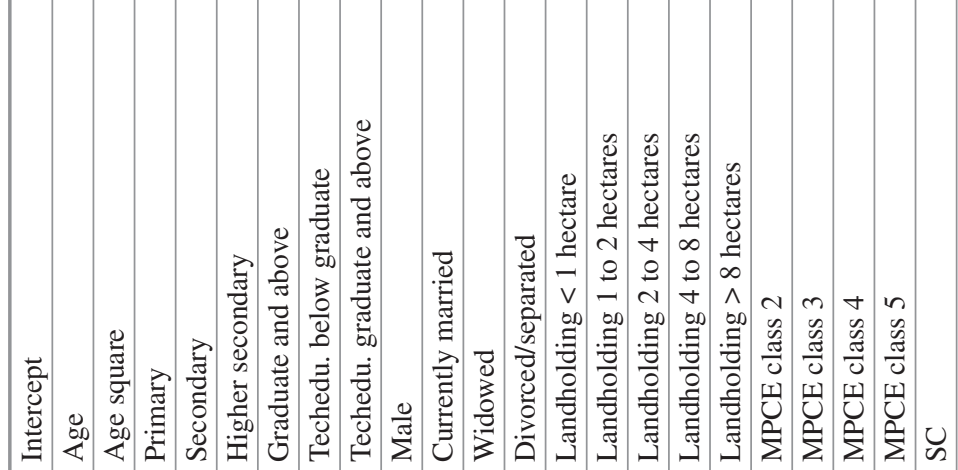




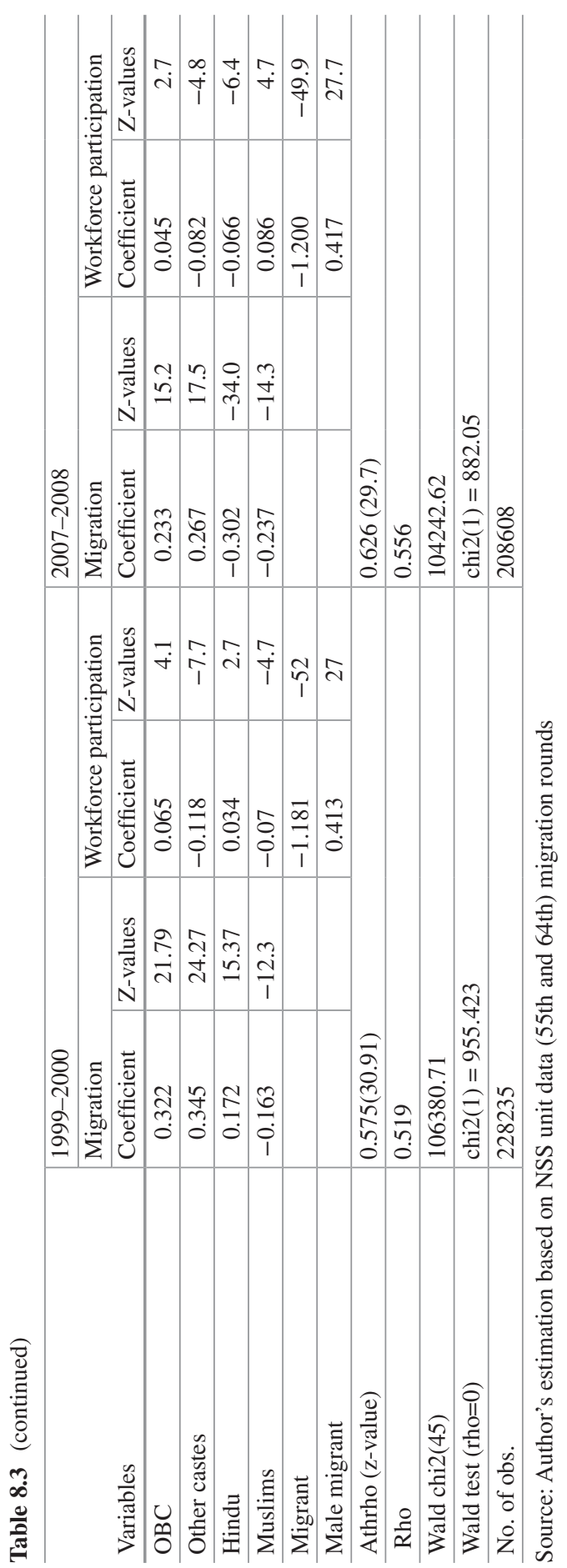


that the probability of migration and workforce participation among Hindus is high in comparison to Muslims and other religions (reference category).

Since a huge number of persons migrated from rural areas to urban India during the periods of high economic growth, it is important to know whether this transition brings about any change in their productivity in the urban areas. The productivity of the migrant and non-migrant workers can be measured through the estimation of their daily wages/earnings (a proxy measure).

\section{Migration, Wage Determinants, and Differentials in Urban India}

When the log of monthly wage is plotted (see Fig. 8.3), it is observed that migrants' wage distribution is positioned rightward to the non-migrants' wage distribution. This suggests that migrants, on average, tend to earn higher than non-migrants. To have a clear picture of this differential, we plot the earnings distributions by their employment status. It is clear (Fig. 8.3, Part B) that, on average, migrant regular employees are better paid as compared to their non-migrant counterparts, as their wage distribution is placed to the right of non-migrants' wage distribution. However, the wage distribution of casual workers shows an interesting pattern particularly in 2007-2008. The earnings distribution of migrants is slightly placed toward the left of non-migrants' distribution in the lower quintiles (well before median wage), but it is located toward the right to the non-migrants' wage distribution throughout the upper quintiles (including the median wage). This indicates the fact that even within casual (informal) employment, migrant workers are better paid than their nonmigrant counterparts.

The average daily wages of migrant and non-migrant, regular-salaried and casual workers are given in Table 8.4 by industry and occupation. From the figures of the average daily wages of migrants and non-migrants in various industries, it is clear that except in the agriculture and allied sector in 2007-2008 and casual employment in the real estate (only in 2007-2008) and other service sectors, in all other industries, irrespective of the types of employment, migrant workers, on average, earn more than that of their non-migrant counterparts. The mean wage difference between migrants and non-migrants within regular-salaried employment was about Rs. 23, while in the case of casual employment, it was about Rs. 2.50 during 1999-2000. This difference was also noticed during 2007-2008 for regular-salaried workers, but the reverse was seen for casual workers. The mean wage difference between migrants and non-migrants within regular-salaried employment was about Rs. 55, while in the case of casual employment, it was negative Rs. 2.70 in 2007-2008.

During 1999-2000, migrant casual workers in the agriculture and allied sector (Rs. 6) and other service (Rs. 5) sectors, on average, earn less than non-migrants. However, in all other sectors, regardless of the types of employment, the absolute 


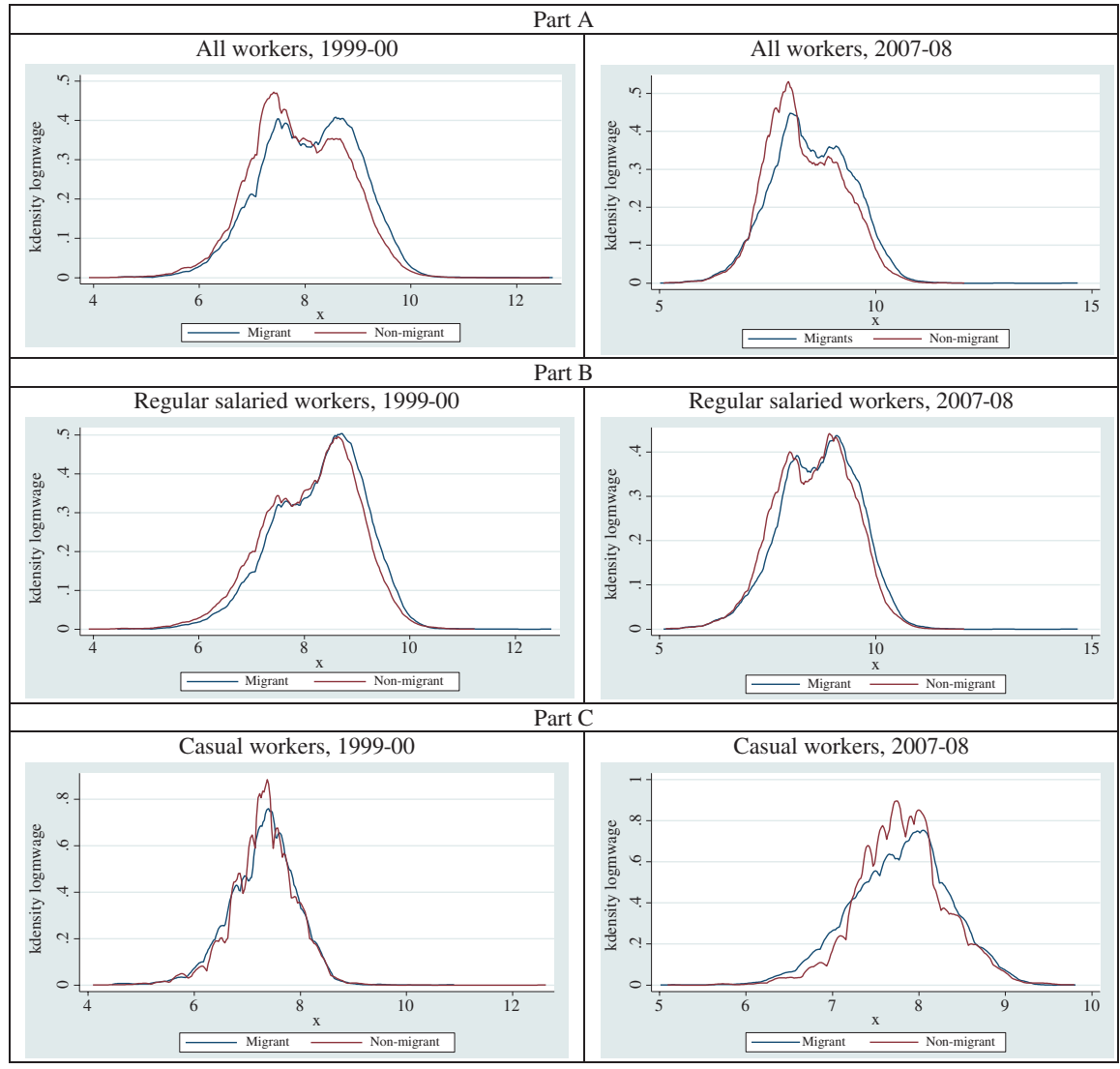

Fig 8.3 Distribution of log monthly wage/earning of migrants and non-migrants' in urban India, 1999-2000 and 2007-2008. (Source: Author's estimation based on NSS unit data (55th and 64th) migration rounds)

difference in average daily wages favors the migrants. The mean wage difference was highest among regular-salaried workers in real estate and finance (Rs. 83); mining and quarrying (Rs. 52); hotel, trade, and restaurant (Rs. 22); transport and communication (Rs. 21); manufacturing (Rs. 19); and electricity, gas, and water (Rs. 18), respectively. Further, within casual employment in the mining and quarrying and real estate and finance sectors, it is also observed that migrant workers earn Rs. 26 and Rs. 17, respectively, more than non-migrants.

During 2007-2008, the mean wage difference within regular-salaried employment favors the migrants in all sectors but agricultural and allied. And within casual employment, the mean wage difference favors the migrants in all sectors except agricultural and allied, real estate and finance, and other service sectors. The average wage difference between migrants and non-migrants within regular-salaried workers was highest in sectors like real estate and finance (Rs. 160); electricity, gas, and water (Rs. 98); transport and communication (Rs. 69); construction (Rs. 56); 
Table 8.4 Average daily nominal wages (Rs.) of migrants and non-migrants by industry of employment and occupation in urban India, 1999-2000 and 2007-2008

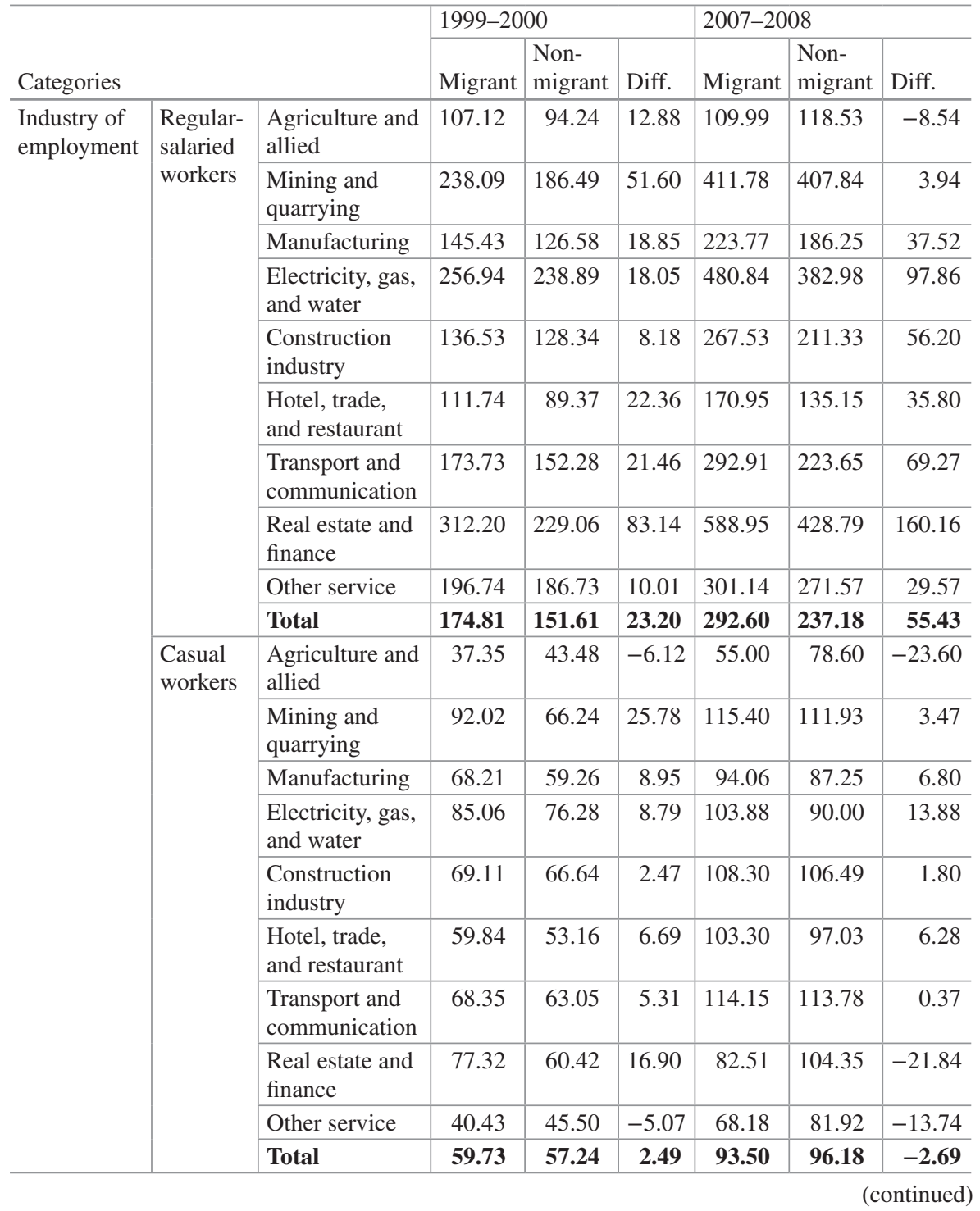


Table 8.4 (continued)

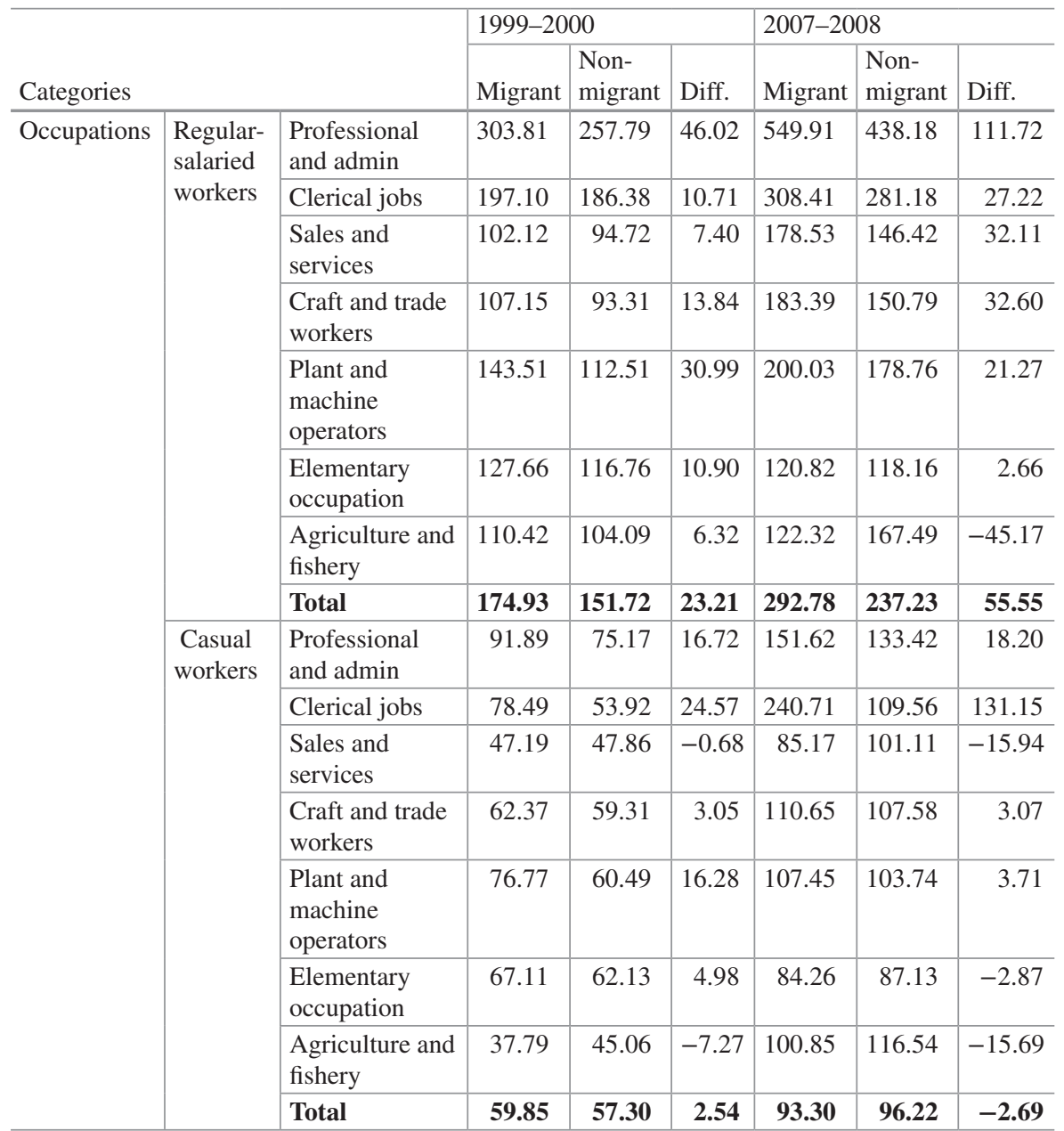

Source: Author's estimation based on NSS unit data (55th and 64th) migration rounds

manufacturing (Rs. 37.50); and hotel, trade, and restaurant (Rs. 36), respectively. Within casual employment, this difference was highest in electricity, gas, and water (Rs. 14); manufacturing (Rs. 7); hotel, trade, and restaurant (Rs. 6); and construction (Rs. 2). The negative values in the agricultural and allied (Rs. 24), real estate and finance (Rs. 22), and other service (Rs. 14) sectors lead to a Rs. 2.70 (negligible) wage difference in favor of non-migrant workers. These negligible differences within casual employment, however, do not affect the overall wage difference.

A similar conclusion can be drawn from the occupation-wise average daily wages of migrant and non-migrant workers. Within regular-salaried employment, migrant workers earn more than non-migrants in all occupations, with the only exception being agriculture and fishery in 2007-2008, while migrant workers within 
casual employment earn more than non-migrants in all other occupations except agriculture and fishery, sales and services, and elementary occupations. It can be noted that the average daily wage/earning difference is highest among highly skilled workers and vice versa. Within regular-salaried employment, the absolute wage difference was highest among professionals and administrative workers (Rs. 46 in 1999-2000 and Rs. 112 in 2007-2008), and this is followed by craft and trade workers (Rs. 14 in 1999-2000 and Rs. 32.60 in 2007-2008), plant and machine operators (Rs. 31 in 1999-2000 and Rs. 21 in 2007-2008), sales and services (Rs 7 in 19992000 and Rs. 32 in 2007-2008), and clerical (Rs 11 in 1999-2000 and Rs. 27 in 2007-2008) occupations, respectively. A similar observation is made in the case of casual employment with a few exceptions.

In a transition phase that the Indian economy is presently going through, this wage difference is anticipated as it leads to more economic growth. Rural to urban migration would enhance economic growth if and only if the productivity of the migrants increased because of migration. Before drawing any conclusion, it is important to know the factors determining these wage/earning differences in urban India.

Migrants' and non-migrants' wage equations are specified to include a set individual and establishment variables explaining the earning/wage ratio. The estimated results (see Table 8.5 ) show that the overall model is significant. The statistically significant coefficients of the selectivity variables (hence the absence of these selection variables in the model would have produced bias estimates) imply that there exist correlations between some unobservable factors that are likely to influence migration, workforce participation as well as wage/earning functions simultaneously.

Individual characteristics like age, sex, level of education, marital status, etc. influenced wage/earning. Age (a proxy for experience) positively affects wages, and it reflects the true labor market phenomenon, as its squared term has produced a negative sign in both the equations, implying negative returns to experience in the most advanced ages of the life cycle. The coefficients of the male dummy in both the equations imply that male workers (both migrants and non-migrants) are earning more as compared to female workers. This is as expected as earlier studies (Duraisamy 2002; Mukherjee 2007; Barua 2010; and Das 2012) have found that men are likely to earn more than women in India. Furthermore, a relative stronger coefficient in the migrants' equation implies that the male-female wage gap is high in the case of migrants as compared to non-migrants.

The level of education turned out to be the most important determinant of migrant and non-migrant wages in urban India. The statistically significant and expected signs of the six (four general education and two technical education) education dummies confirmed a positive relation between wage and education. The greater the levels of education, the greater will be the wage income. A relatively stronger coefficient of the general education dummy in the case of migrants implies that with the same level of general education, migrants tend to earn more. A similar result is found when the coefficients of different occupations are compared. The workers in agriculture and fishery and in elementary occupations earn less than that of those who are engaged in semiskilled and highly skilled occupations. This result is as expected. 


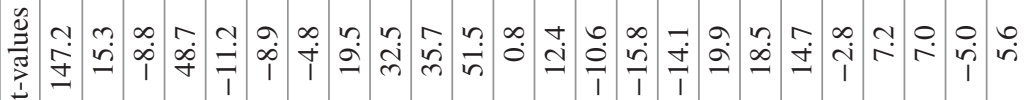

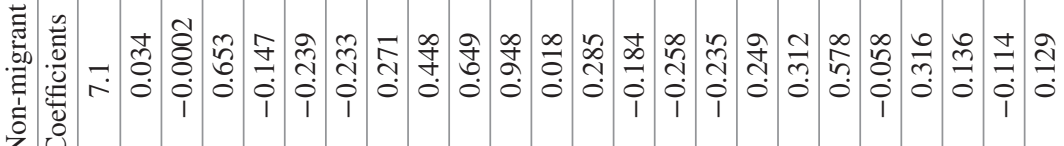

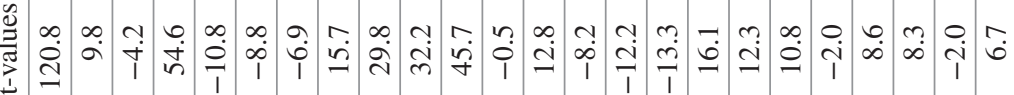

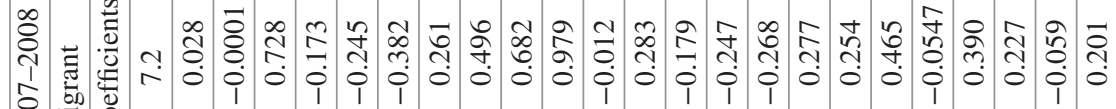
官

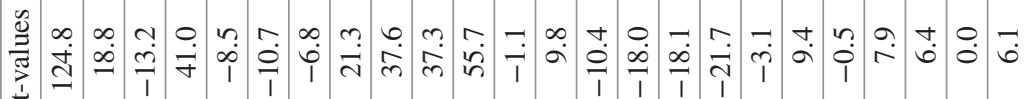

$\underset{\Xi}{\mathscr{g}}$

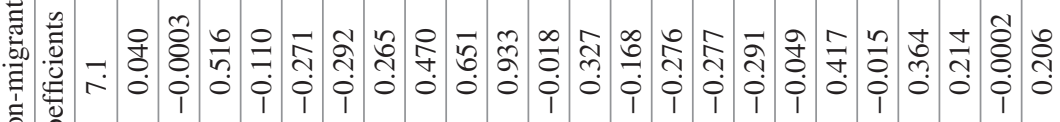

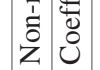

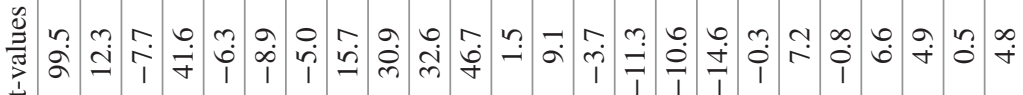

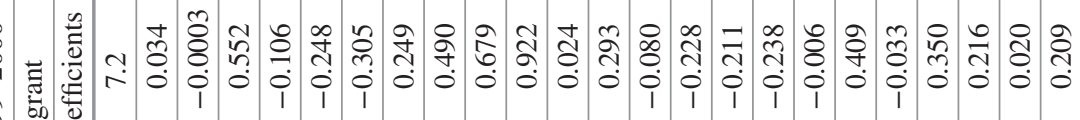
รे $\sum^{5}$

.

告

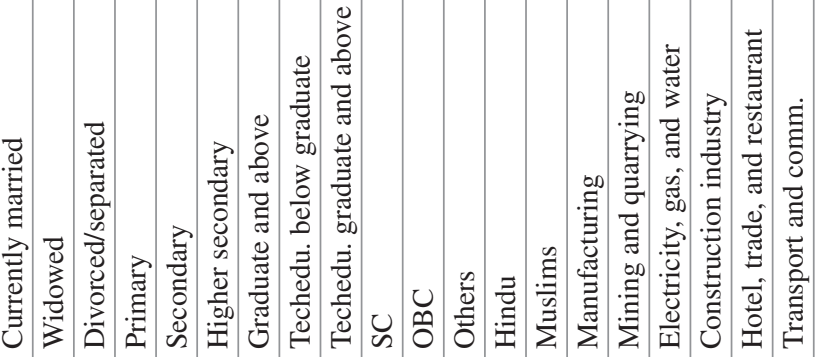




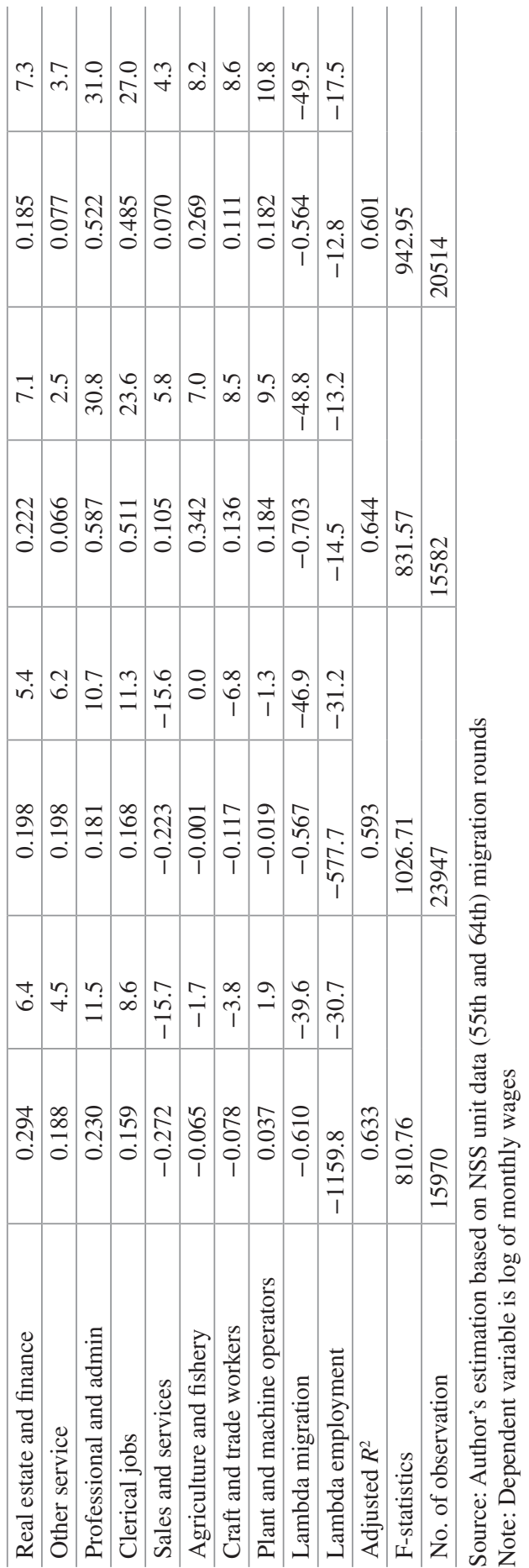


Table 8.6 Summary of Oaxaca-Blinder decomposition

\begin{tabular}{l|c|c}
\hline Summary of decomposition & $1999-2000$ & $2007-2008$ \\
\hline Amount attributable & -25.7 & -4.6 \\
\hline $\begin{array}{l}\text { Amount attributable due to } \\
\text { endowments (E) }\end{array}$ & -21.1 & -16.5 \\
\hline $\begin{array}{l}\text { Amount attributable due to } \\
\text { coefficients (C) }\end{array}$ & -4.6 & 12.0 \\
\hline $\begin{array}{l}\text { Amount attributable shift } \\
\text { coefficient (U) }\end{array}$ & 3.7 & -13.2 \\
\hline Raw differential (R) $\{\mathrm{E}+\mathrm{C}+\mathrm{U}\}$ & -22.0 & -17.8 \\
\hline Adjusted differential (D) $\{\mathrm{C}+\mathrm{U}\}$ & -0.8 & -1.3 \\
\hline Endowments as\% total (E/R) & 96.2 & 92.9 \\
\hline Discrimination as\% total (D/R) & 3.8 & 7.1 \\
\hline
\end{tabular}

Source: Author's estimation based on NSS unit data (55th and 64th) migration rounds

Note: A negative number indicates an advantage for migrants and a disadvantage for non-migrants

The coefficients of the industries of employment reflect that, on average, the wages of workers working in all industries are greater than that of workers in the agriculture and allied sectors except mining and quarrying in 1999-2000 and except mining and quarrying and hotel, trade, and restaurant services in 2007-2008. This is an interesting result that indicates how people from agriculture are attracted to non-agricultural employment. The relatively higher wages in these sectors might have pulled a significant volume of agricultural workers to these sectors in recent years, as the workers in these sectors, on average, earn better than the workers in agriculture.

The relatively stronger coefficients of migrants' industry dummies raise the question whether these wage differentials are due to the difference in productivity or favorable treatment toward migrant workers. To answer this question, we use Oaxaca-Blinder (OB) decomposition results because these results show how much the wage gap is due to a difference in endowments and due to discrimination (or favor). The decomposition result based on Blinder's (1973) original formulation is presented in Table 8.6.

Comparing the output of the migrants' and non-migrants' wage equations, it is clear that migrants have higher constants values. This implies about $13.2 \%$ advantage during 2007-2008. The variables that play a major role include age, sex, level of education, etc. The group difference is found as $6.5 \%$. Around $92.9 \%$ of the wage/earning difference is due to a difference in endowments or productivity, and only $7.1 \%$ of this difference is unexplained. The decomposition based on Oaxaca and Ransom (1994) on the other hand suggests that about $98.4 \%$ is due to endowments or productivity differences (see Table 8.7 ), and only $2 \%$ is due to unexplained factors (see Appendix Table 8.9 for the detailed result). 
Table 8.7 Oaxaca-Blinder twofold (pooled) decomposition

\begin{tabular}{l|l|l|l|l}
\hline \multirow{2}{*}{ Overall } & $1999-2000$ & 2007-2008 & \\
\cline { 2 - 5 } Migrant & Coefficients & SE & Coefficients & SE \\
\hline Non-migrant & 8.096 & 0.007 & 8.519 & 0.007 \\
\hline Difference & 0.220 & 0.006 & 8.341 & 0.006 \\
\hline Explained & $0.218(99.3 \%)$ & 0.009 & 0.178 & 0.010 \\
\hline Unexplained & $0.001(0.7 \%)$ & 0.006 & $0.175(98.4 \%)$ & 0.008 \\
\hline
\end{tabular}

Source: Author's estimation based on NSS unit data (55th and 64th) migration round

The present finding is similar to the findings of Nakosteen and Zimmer (1980) in the United States, Robinson and Tomes (1982) in Canada, Ahmed (1998) in Pakistan, Margirier (2006) in France, and Nanfosso and Akono (2009) in Cameroon. They also have found that migrant workers are more productive than natives and they tend to earn higher wages compared to natives. However, this result is contradictory to the findings of Chiswick (1978), Borjas (1985), and Portes and Bach (1985) in the United States, Knight and Sabot (1982) in Tanzania, and Banerjee and Knight (1985) and Duraisamy and Narasimhan (1997) in India, who found that migrants tend to earn less than non-migrants.

Banerjee and Knight (1985) conducted their study in Delhi, focusing on the caste discrimination among rural migrants in the urban labor markets, doing a comparative analysis of formal and informal sectors' cadre-wise workers, whereas Duraisamy and Narasimhan (1997) estimated the wage differential between migrants and native workers in the informal sector using the survey data from Chennai. Both studies found significant wage/earning differentials. This is due to the discriminatory treatment of migrant workers in the informal sector. This result is just in contrast to what they have found in Delhi and Chennai. The recent growth of the informal sector and implementation of the informal workers' laws, particularly the social security measures to protect these workers, might have improved their bargaining power, which is partly reflected by improved earnings/wages in the case of casual employment.

\section{Conclusion}

During the period of high economic growth, a "Lewisian transition" is taking place in India. About 5 million persons per year are out-migrating from rural India, of which about 3 million per year are coming to urban areas. The rural out-migration rate is high in most of the poor and backward states, which are mostly agrarian. Mechanization in agriculture is driving rural-urban migration in India. An increasing number of people are migrating to the relatively advanced states, particularly toward relatively modernized medium-sized cities and to large metro cities. Though a proportion of rural to urban migrants are working as regular workers in urban India, due to the rapid 
growth of rural to urban migration, both the size of the urban population and the share of casual and informal employment among migrants increased in urban India.

The working of push and pull factors simultaneously determines rural-urban migration in India. The high incidence of poverty, growing mechanization in agriculture, and lack of suitable job opportunities in the rural areas push a large number of people out of rural areas in search of employment and living. Furthermore, with increasing mean years of schooling and growing enrollments in higher education and technical and vocational education, a large number of young job aspirants are moving toward the urban areas for employment. This is also reflected by the migrants' labor force participation in urban India. The rural to urban migration not only causes the growth of the urban population and informal sector activities but also creates a competitive environment for all urban job seekers. This is partly evident from the relatively higher average wages/earnings of migrants than their nonmigrant counterparts in most of the sectors (including manufacturing, construction, electricity, gas and water, hotel trade business, transport and communications, etc.) in which migrants are engaged. Furthermore, the overall wage differentials favor migrants with a $98.4 \%$ difference owing to the difference in productivity in 2007-2008.

Since rural to urban migration is an outcome of the higher economic growth and structural changes that are occurring in both output (GDP) and employment in India, an increase in labor productivity after migration would help speed up this process. The volume of rural-urban migration is expected to increase further given that huge numbers of children are currently participating in higher education. Hence, the proposal of increasing investment in infrastructure and creating a number of medium-sized (tier-III) cities in India would absorb a large number of rural to urban unskilled (those who are leaving agriculture) and semiskilled migrant workers. This would partly solve the problems of urban housing and growth of slums in large metro cities. Hence, a long-term (might be 15 to 20 years) planned investment in infrastructure, including the construction of roads, dams (for the management of river water for irrigation and production of electricity), electricity projects, housing and telecommunications, etc. would not only sustain the growth of output and employment but also help sustain the urbanization process in India. Furthermore, the government should focus on (i) initiating a new set of reform measures for strengthening labor-intensive manufacturing units in micro-, small-, and mediumsize enterprises for assisting these enterprises to grow further and enabling them to create more jobs and (ii) expanding service sectors like education, health, and public administration and security (to counter the increasing insecurity among women) by increasing the share of government expenditure on these sectors which would also create a number of jobs in urban areas. These policies would help accommodate the increasing number of both skilled and unskilled migrant workers and would sustain the growth process in India. 


\section{Appendix}

Table 8.8 Distribution of workers $(\mathrm{PS}+\mathrm{SS})$ by sectors and types of employment in India, 1993-2012

\begin{tabular}{|c|c|c|c|c|c|c|c|c|c|c|}
\hline \multirow[b]{2}{*}{ Sectors } & & \multicolumn{5}{|c|}{ No. of workers (million) } & \multicolumn{4}{|c|}{$\begin{array}{l}\text { Change in employment } \\
\text { (million) }\end{array}$} \\
\hline & & $\begin{array}{l}1993- \\
1994\end{array}$ & $\begin{array}{l}1999- \\
2000\end{array}$ & $\begin{array}{l}2004- \\
2005\end{array}$ & $\begin{array}{l}2009 \\
2010\end{array}$ & $\begin{array}{l}2011- \\
2012\end{array}$ & $\begin{array}{l}1994- \\
2000\end{array}$ & $\begin{array}{l}2000 \\
2005\end{array}$ & $\begin{array}{l}2005- \\
2010\end{array}$ & $\begin{array}{l}2010 \\
2012\end{array}$ \\
\hline \multicolumn{11}{|c|}{ Types of employment in agriculture and allied sectors } \\
\hline \multirow[t]{6}{*}{$\begin{array}{l}\text { Agriculture } \\
\text { and allied }\end{array}$} & $\begin{array}{l}\text { Own } \\
\text { account } \\
\text { worker }\end{array}$ & 67.8 & 70.4 & 78.5 & 76.3 & 80.8 & 2.5 & 8.2 & -2.2 & 4.5 \\
\hline & Employer & 5.0 & 2.6 & 3.2 & 2.8 & 3.4 & -2.4 & 0.7 & -0.5 & 0.6 \\
\hline & $\begin{array}{l}\text { Unpaid } \\
\text { family } \\
\text { worker }\end{array}$ & 72.3 & 69.5 & 90.6 & 68.0 & 66.9 & -2.8 & 21.1 & -22.5 & -1.1 \\
\hline & $\begin{array}{l}\text { Regular } \\
\text { workers }\end{array}$ & 3.3 & 3.5 & 2.9 & 2.1 & 1.9 & 0.2 & -0.7 & -0.7 & -0.2 \\
\hline & $\begin{array}{l}\text { Casual } \\
\text { workers }\end{array}$ & 93.1 & 100.6 & 93.3 & 95.6 & 78.9 & 7.5 & -7.3 & 2.3 & -16.7 \\
\hline & Total & 241.5 & 246.6 & 268.5 & 244.9 & 231.9 & 5.0 & 22.0 & -23.7 & -13.0 \\
\hline \multicolumn{2}{|c|}{ Industry total } & 54.7 & 63.1 & 83.3 & 99.0 & 115.0 & 8.4 & 20.2 & 15.8 & 16.0 \\
\hline \multicolumn{2}{|c|}{ Services total } & 77.7 & 89.8 & 107.3 & 116.3 & 127.3 & 12.1 & 17.5 & 9.1 & 11.0 \\
\hline \multicolumn{2}{|l|}{ All Sectors } & 374.0 & 399.5 & 459.0 & 460.2 & 474.3 & 25.5 & 59.5 & 1.2 & 14.1 \\
\hline
\end{tabular}

Source: Calculation using NSS unit-level data from various employment rounds

Note: PS, principal status (worked at least 180 days in a particular job), and SS, subsidiary status (worked at least 30 days but less than 180 days in a particular job) 


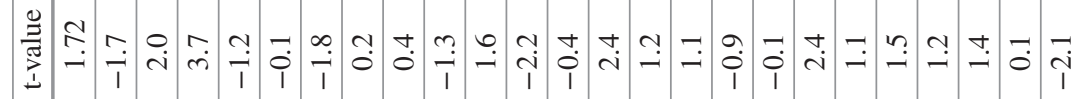

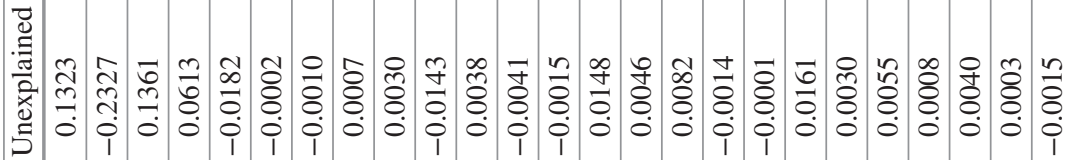

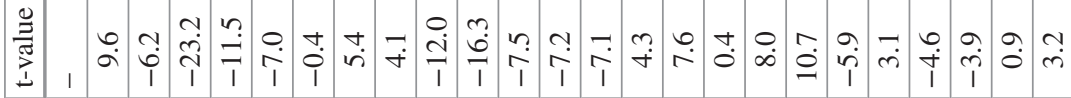

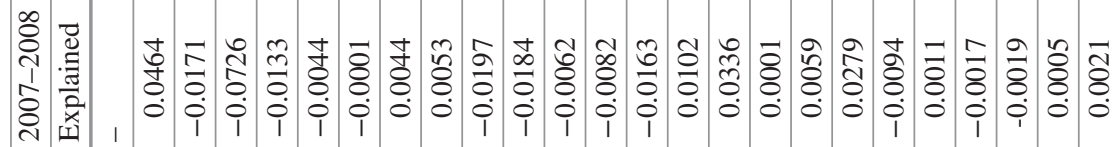

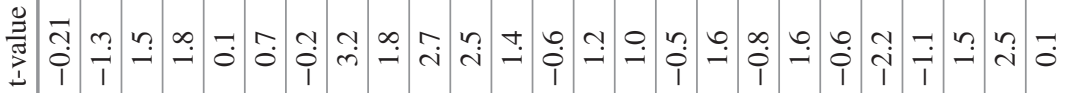

$\overline{\breve{v}}$

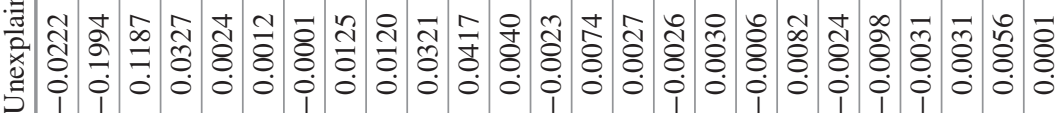

言

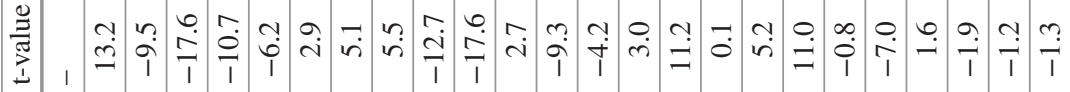

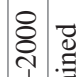

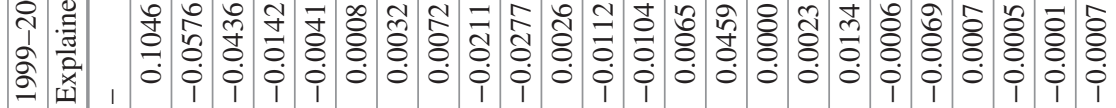

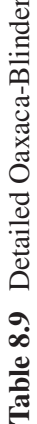

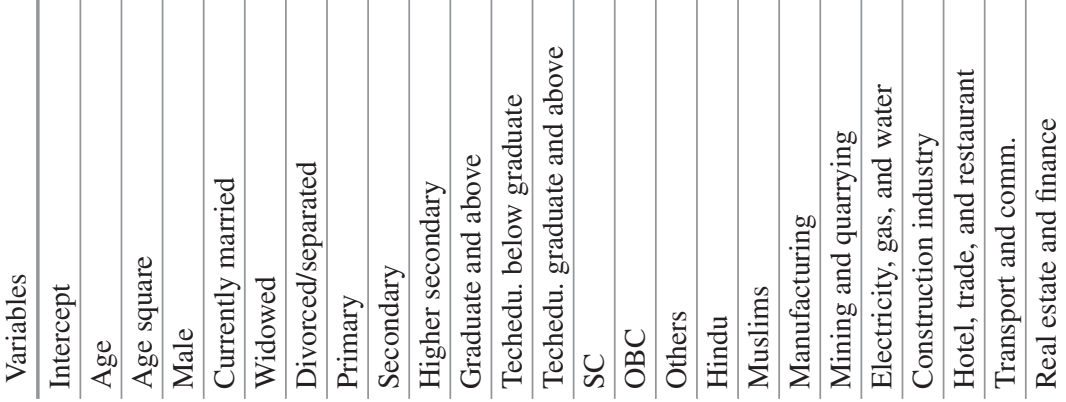




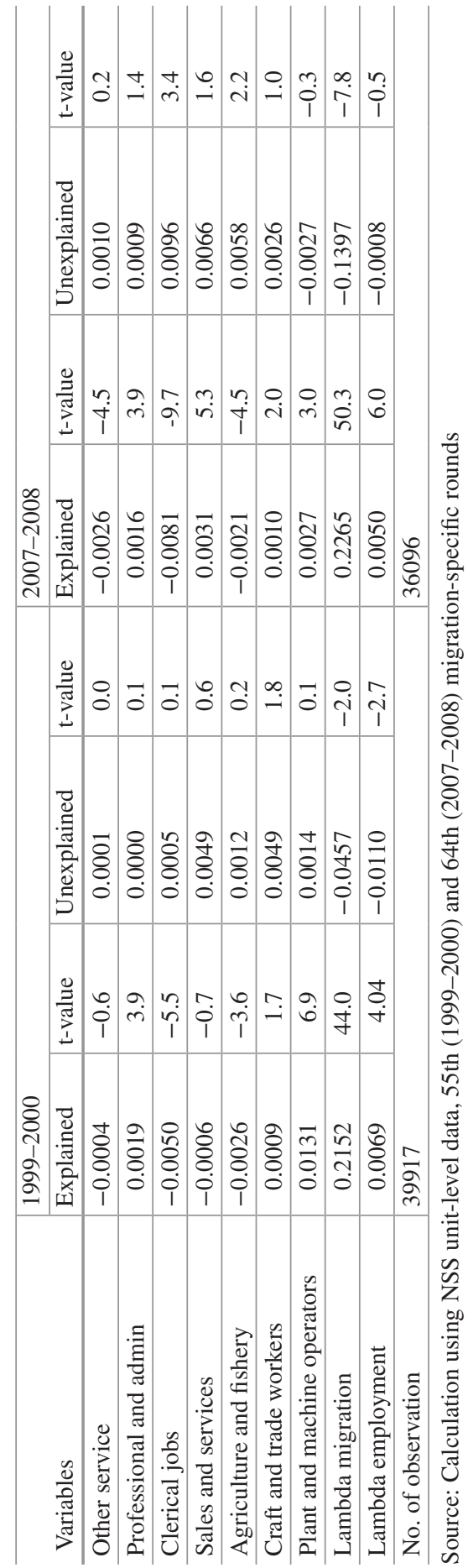




\section{References}

Abraham. (2008). Employment growth in rural India: Distress driven? (Working Paper 404). Available at http://vinojabraham.ucoz.com/geo_export/0/wp404.pdf, Accessed on 4 Aug 2014.

Ahmed, A. M. (1998). Sources of earnings differentials among migrants and natives. Pakistan Development Review, 37(4), 939-953.

Banerjee, B., \& Knight, J. B. (1985). Caste discrimination in the Indian labor market. Journal of Development Economics, 17(3), 277-307.

Barua, K. (2010). Variation in wage earnings among agricultural laborers in rural bengal: A fieldwork-based analysis. Indian Journal of Labour Economics, 53(4), 677-686.

Bhattacharya, P. C. (2002). Urbanization in developing countries. Economic and Political Weekly, $37(41), 4219-4228$.

Blinder, A. S. (1973). Wage discrimination: Reduced form and structural estimates. Journal of Human Resources, 8(4), 436-455.

Borjas, B. J. (1985). Assimilation, changes in cohort quality, and earnings of immigrants. Journal of Labour Economics, 3(4), 463-489.

Chiswick, B. (1978). The effect of americanization on the earnings of foreign-born men. Journal of Political Economy, 86(5), 897-921.

Connell, J. B., Das Gupta, L., \& Lipton, M. (1976). Migration from rural areas: The evidence from village studies. New Delhi: Oxford University Press.

Cotton, C. J. (1988). On the decomposition of wage differentials. Review of Economics and Statistics, 70(2), 236-243.

Das, P. (2012). Wage inequality in India decomposition by sector, gender and activity status. Economic Political Weekly, XLVII(50), 58-64.

Deshingkar, P., \& Akter, S. (2009). Migration and human development in India (Human Development Research Paper, No. 13). UNDP.

Dupont, V. (1992). Impact of In-Migration on industrial development: Case study of Jetpur in Gujarat. Economic and Political Weekly, 27(45), 2423-2436.

Duraisamy, P. (2002). Changes in returns to education in India, 1983-94: By gender, age-cohort and location. Economics of Education Review, 21(6), 609-622.

Duraisamy, P., \& Narasimhan, S. (1997). Wage differentials between migrants and non-migrants and discrimination in urban informal sector in India. Indian Journal of Labour Economics, $40(2), 223-235$.

Gill, A., \& Singh, L. (2006). Farmers' suicides and response of public policy: Evidence, diagnosis and alternatives from Punjab. Economic and Political Weekly, 41(26), 2762-2768.

Gulati, A.,Jain, S., \& Satija, N. (2013). Rising farm wages in India: The 'Pull' and 'Push' factors (Discussion Paper No. 5). New Delhi: Commission for Agricultural Costs and Prices, Dept. of Agriculture \& Cooperation, Ministry of Agriculture, Government of India.

Heckman, J. (1979). Sample selection bias as a specification error. Econometrica, 47(1), 153-161.

Himanshu. (2011). Employment trends in India: A Re-examination. Economic and Political Weekly, 46(37), 43-59. 
Indian Institute for Human Settlements, Urban India. (2011). Evidence. http://iihs.co.in/knowledge-gateway/wp-content/uploads/2015/08/IUC-Book_02-03-12-LOW-RES.pdf viewed on $14 / 12 / 2018$.

Jeromi, P. D. (2007). Farmers' indebtedness and suicides: Impact of agricultural trade liberalisation in Kerala. Economic and Political Weekly, 42(31), 3241-3247.

Joshi, H., \& Joshi, V. (1976). Surplus labor and the City: A study of Bombay. Bombay: Oxford University Press.

Kannan, K. P., \& Raveendran, G. (2012). Counting and profiling the missing labor force. Economic and Political Weekly, XLVII(6), 77-80.

Knight, J. B., \& Sabot, R. H. (1982). Labor market discrimination in a poor urban economy. Journal of Development Studies, 19(1), 67-87.

Kundu, A., \& Gupta, S. (1996). Migration, urbanization and regional inequality. Economic and Political weekly, 31(52), 3391-3398.

Lewis, A. (1954). Economic development with unlimited supplies of labor. Manchester School of Economic and Social Studies, 22, 139-191.

Madheswaran, S., \& Attewell, P. (2007). Caste discrimination in the Indian urban labour market: Evidence from the National Sample Survey. Economic and Political Weekly, 42(41), 4146-4153.

Margirier, G. (2006). Mobilitégéographiqueet salaries à l'entréesur le marché du travail. Revue d'EconomiePolitique, 116(5), 657-679.

Mehrotra, S., \& Parida, J. K. (2017). Why is the labour force participation of women declining in India? World Development, 98, 360-380.

Mehrotra, S., Parida, J., Sinha, S., \& Gandhi, A. (2014). Explaining employment trends in the Indian economy: 1993-4 to 2011-12. Economic and Political Weekly, XLIX(32), 49-57.

Mincer, J. (1974). Schooling experience and earnings. New York: Columbia University Press.

Mitra, A. (2003). Occupational choices, networks and transfers: An exegesis based on micro data from Delhi Slums. New Delhi: Manohar.

Mitra, S., \& Shroff, S. (2007). Farmers' suicides in Maharashtra. Economic and Political Weekly, 42(49), 73-77.

Mukherjee, D. (2007). Post-reform trends in wage-differentials: A decomposition analysis for India (MPRA Paper No. 12754). Available at http://mpra.ub.uni-muenchen.de/12754/

Nakosteen, R. A., \& Zimmer, M. (1980). Migration and income: The question of self-selection. Southern Economic Review, 46(3), 840-851.

Nanfosso, R. T., \& Akono, C. Z. (2009). Migration and wages differentials in urban Cameroon. Research in Applied Economics, 1(1), 1-14.

Neumark, D. (1988). Employers discriminatory behaviour and estimation of wage discrimination. Journal of Human Resources, 23(3), 279-295.

Oaxaca, R. L. (1973). Male-Female wage differentials in urban labor market. International Economic Review, 14(3), 693-709.

Oaxaca, R. L., \& Ransom, M. R. (1994). On discrimination and the decomposition of wage differentials. Journal of Econometrics, 61(1), 5-21.

Parida, J. K. (2015). Growth and prospects of Non-farm employment in India: Reflections from NSS data. The Journal of Industrial Statistics, 4(2), 154-168. 
Portes, A., \& Bach, R. L. (1985). Latin journey: Cuban and Mexican immigrants in the United States. Univ of California Press.

Rangarajan, C., Padma, I. K., \& Seema. (2011). Where is the missing labor force? Economic and Political Weekly, 46(39), 68-72.

Reimer, C. W. (1983). Labour market discrimination against hispanic and black men. Review of Economics and Statistics, 65(4), 570-579.

Robinson, C., \& Tomes, N. (1982). Self-selection and interprovincial migration in Canada. Canadian Journal of Economics, 15(3), 474-502.

Singh, C. S. K. (2002). Daily labor market in Delhi: structure and behaviour. Economic and Political Weekly, 37(9), 884-889.

Srivastava, R. (1998). Migration and the labor market in India. Indian Journal of Labour Economics, 41(4), 583-616.

Srivastava, R. S., \& Bhattacharyya, S. (2002). Globalization, reforms and internal labor mobility: Analysis of recent Indian trends. Paper presented at a seminar 'Labour Mobility and Globalising World: Conceptual and Empirical Issues' during Sept, 2002, V.V. Giri National Labour Institute. New Delhi.

Thomas, J. (2012). India's labor market during the 2000s: Surveying the changes. Economic and Political Weekly, XLVII(51), 39-51.

Vijay, G. (2005). Migration, vulnerability and insecurity in new industrial labor markets. Economic Political Weekly, 40(22/23), 2304-2312.

The views expressed in this publication are those of the authors and do not necessarily reflect the views and policies of the Asian Development Bank (ADB) or its Board of Governors or the governments they represent.

ADB does not guarantee the accuracy of the data included in this publication and accepts no responsibility for any consequence of their use. The mention of specific companies or products of manufacturers does not imply that they are endorsed or recommended by ADB in preference to others of a similar nature that are not mentioned.

By making any designation of or reference to a particular territory or geographic area, or by using the term "country" in this document, $\mathrm{ADB}$ does not intend to make any judgments as to the legal or other status of any territory or area.

Open Access This work is available under the Creative Commons Attribution-NonCommercial 3.0 IGO license (CC BY-NC 3.0 IGO) http://creativecommons.org/licenses/by-nc/3.0/igo/. By using the content of this publication, you agree to be bound by the terms of this license. For attribution and permissions, please read the provisions and terms of use at https://www.adb.org/ terms-use\#openaccess.

This CC license does not apply to non-ADB copyright materials in this publication. If the material is attributed to another source, please contact the copyright owner or publisher of that source for permission to reproduce it. ADB cannot be held liable for any claims that arise as a result of your use of the material.

Please contact pubsmarketing@adb.org if you have questions or comments with respect to content, or if you wish to obtain copyright permission for your intended use that does not fall within these terms, or for permission to use the ADB logo. 